\title{
The association between symptoms and bladder or renal tract cancer in primary care:
}

\section{a systematic review}

\begin{abstract}
\section{Background}

Appropriate selection for further investigation of patients presenting in primary care with symptoms that may indicate cancer is key to early diagnosis.

\section{Aim}

To quantify the risk of urinary tract cancer in patients presenting in primary care with symptoms that may indicate bladder or renal cancer.
\end{abstract}

\section{Design and setting}

Systematic review of studies relating to bladder or renal cancer in primary care.

\section{Method}

Databases searched were MEDLINE, PreMEDLINE, Embase, the Cochrane Library, Web of Science (SCl and SSCI), and ISI Proceedings from 1980 to August 2014. and PsycINFO (1980-2012) and BioMed Central (inception to 2012) for retrospective, prospective, or case-control diagnostic accuracy studies of symptomatic patients presenting to primary care with one or more symptoms for whom follow-up data were available. The target conditions were bladder or renal cancer. The studies were appraised using the QUADAS-2 tool.

\section{Results}

Eleven studies with 3451675 patients were included. The positive predictive value (PPV) from meta-analysis of visible haematuria was $5.1 \%$ in adult patients. It increased with age and was higher in males. The PPVs of other single symptoms were very low, with the highest non-haematuria PPV being 1.4\% for anaemia in males. Fewer data were available on the PPVs of symptom combinations. Generally, these data showed that, with the exception of symptom combinations including haematuria, these were very low.

\section{Conclusion}

The only high-risk feature of bladder/renal cancer in primary care was visible haematuria, and this clearly warrants investigation.

However, not all patients with one of these cancers experience haematuria, so a policy restricting investigation to patients with haematuria will inevitably delay the diagnosis in some patients.

\section{Keywords}

bladder neoplasms; diagnosis; haematuria; primary care; renal neoplasms; symptoms.

\section{INTRODUCTION}

Urological cancer is common, with 10000 each of bladder and kidney cancers diagnosed in the UK annually. ${ }^{1}$ A further 40000 prostate cancers are diagnosed each year. Five-year survival is $57 \%$ for both bladder and kidney cancers. As usual in cancer, survival is strongly related to stage at diagnosis. No national screening programme for any of these cancers exists in the UK, although prostate cancer screening is recommended in some other countries, so identification of urological malignancies generally follows presentation to primary care with symptoms. The main alternative route to diagnosis is by emergency presentation, with approximately one-quarter of renal or bladder cancers presenting this way. ${ }^{2,3}$ Selection of patients for urological referral depends on the patient's symptoms, plus any abnormal examination findings.

This systematic review was undertaken to inform the selection process, as part of a revision of UK cancer guidance. ${ }^{4}$ The review was restricted to primary care studies, as it is in primary care that the selection process takes place. It included prostate and testicular cancer, although only very few relevant data were found for prostate cancer. for example Hamilton et al ${ }_{i}^{5}$ therefore, this review reports only the findings relating to bladder and renal cancer.

\section{METHOD}

\section{Criteria for considering studies for this} review

The target studies for inclusion were diagnostic accuracy studies treating a

M Schmidt-Hansen, $\mathrm{PhD}$, researcher:

S Berendse, MA, information specialist, National Collaborating Centre for Cancer, Cardiff.

W Hamilton, MD, FRCP, professor of primary care diagnostics, University of Exeter medical School, Exeter.

\section{Address for correspondence}

Mia Schmidt-Hansen, National Collaborating

Centre for Cancer, Park House, Greyfriars Road, symptom as the equivalent of a positive test. These studies were either of a series of unselected or randomly selected patients presenting to primary care with one or more symptoms and with follow-up data available. Studies could be prospective or retrospective, or diagnostic case-control studies where cases were patients with bladder or renal cancer, and controls were (matched) patients without urinary tract cancer that reported the prevalence of the symptoms before diagnosis in both patient groups.

\section{Search methods for identification of studies}

MEDLINE, PreMEDLINE, Embase, the Cochrane Library, Web of Science $(\mathrm{SCl}$ and SSCI), and ISI Proceedings from 1980 to 11 August 2014 (bladder cancer) or to 18 August 2014 (renal cancer) as well as PsycINFO (1980 to 3 September 2012 for bladder cancer; 1980 to 10 December 2012 for renal cancerl and BioMed Central linception to 12 September 2012 for bladder cancer; inception to 11 December 2012 for renal cancerl, were searched using two separate search strategies, one for bladder cancer and one for renal cancer ffurther details available from the authors on request). The initial search results were screened, excluding all obviously irrelevant studies. The titles and abstracts of the remaining records were also screened, excluding irrelevant studies while examining the full text of all potentially relevant studies. The final lists of included and excluded studies were agreed in consensus.
Cardiff CF10 3AF, UK.

E-mail: mia.schmidt-hansendwales.nhs.uk Submitted: 18 May 2015; Editor's response: 5 June 2015; final acceptance: 18 June 2015. (C)British Journal of General Practice

This is the full-length article (published online 26 Oct 2015) of an abridged version published in print. Cite this article as: Br J Gen Pract 2015; DOI: 10.3399/bjgp15X687421 


\section{How this fits in}

Investigation for possible bladder or renal cancer is largely performed by urologists, because primary care testing for these cancers is not possible. The headline symptom of these cancers is haematuria although it was recognised that not all patients experienced this. Haematuria remains very important, with a positive predictive value (PPV) of $5.1 \%$ in this meta-analysis. Other symptoms are of low risk, unless they are accompanied by haematuria. The next highest-risk symptom was anaemia, with a PPV of $1.4 \%$ in males.

\section{Data collection and analysis}

Data extraction and quality assessment of the included studies were performed. For each included study the following characteristics were extracted: study design, inclusion/exclusion criteria, setting, patient characteristics lnumber, age, sex, country, any other relevant characteristics reported, such as relevant history or comorbidities), definition of symptom, method of verification of diagnosis, and any other relevant details reported in the studies. The risks of different biases associated with the included studies were assessed using the QUADAS-2 tool for each of the included studies. ${ }^{6}$ For each reported symptom, the number of patients with the symptoms who had urinary tract cancer (true positives) and the number of patients with the symptoms who did not have urinary tract cancer (false positives) were extracted.

From these data positive predictive values (PPVs) were calculated, which formed the basis of the risk estimate. When three or more studies reported a given symptom, the results were meta-analysed to provide a summary estimate indicating the risk of urological cancer associated with the symptom. These analyses were conducted according to the methods outlined by Leeflang and colleagues, ${ }^{7}$ with bivariate meta-analysis of predictive values of diagnostic tests an alternative to bivariate meta-analysis of sensitivity and specificity. Stata (version 11.2) was used for the analyses.

When it was not possible to combine the PPVs for both cancers, for example, due to the design of the studies, then for the purposes of interpretation the PPVs can be considered to be additive. As such, the PPV of constipation for either renal or bladder cancer can be considered to be $0.1 \%+0.1 \%=0.2 \%$

\section{RESULTS}

\section{Results of the search}

The search of all the databases identified 6697 (before de-duplication) possibly relevant papers, of which 6641 papers were excluded based on title/abstract, and 56 papers were obtained for full-text review. Eleven of these 56 papers were included in this review, ${ }^{8-18}$ while 45 were excluded for the following reasons: narrative review In = 15); patients, setting, or outcomes did not meet the inclusion criteria $(n=29)$; and not enough information available to ascertain relevance $(n=1)$.

\section{Characteristics and methodological quality of included studies}

Table 1 provides a summary of the characteristics of the included studies la detailed description and assessment of each study is available from the authors on request). The studies included a total of 3451675 patients and were conducted in the UK, $, 12,13,16-18$ the Netherlands, ${ }^{14,15}$ Belgium, ${ }^{8}$ and the US. ${ }^{10,11}$ The reference standards employed in the studies were all follow-up.

Table 2 summarises the risk-of-bias and applicability assessments for each of the included studies. The main bias and applicability concerns to note in terms of patient selection were that this was not clearly consecutive or random in five of the studies, ${ }^{10,14,16-18}$ with five of these studies conducted in a setting not clearly directly representative of UK-based primary care. $8,10,11,14,15$ The other bias and applicability concerns to note include missing data, ${ }^{12}$ restricted and/or short follow-up, 10,11 and underspecified presenting symptoms. ${ }^{14}$

\section{Findings}

Single symptoms. Tables 3, 4, and 5 list the PPVs for single symptoms combined for both bladder and renal cancer where this was possible, and otherwise separately. The prevalence of visible haematuria was $64 \%$ in patients aged $\geq 40$ years with bladder cancer, ${ }^{16}$ and $18 \%$ in patients aged $\geq 40$ years with renal cancer. ${ }^{18}$ Table 3 shows that the PPV for visible haematuria was higher for bladder cancer than for renal cancer, and increased with age in both cancers. Moreover, visible haematuria had a moderately high PPV even at relatively young ages, which contrasts with the PPVs of non-visible haematuria (with a prevalence in patients with bladder cancer of $6.4 \%)^{16}$ and other single symptoms, none of which were above $1.6 \%$, with the most being well below $1 \%$. However, four studies did not distinguish between visible and non-visible 
Table 1. Characteristics of the included studies

\begin{tabular}{|c|c|c|c|c|c|}
\hline Study & Country & Design & $\begin{array}{l}\text { Total } \\
\text { number } \\
\text { eligible }\end{array}$ & $\begin{array}{l}\text { Patients } \\
\text { with urinary } \\
\text { tract cancer }\end{array}$ & Reference standard \\
\hline $\begin{array}{l}\text { Bruyninckx } \\
(2003)\end{array}$ & Belgium & $\begin{array}{l}\text { Prospective series using a } \\
\text { register populated by GPs }\end{array}$ & 409 & 42 & $\begin{array}{l}\geq 18 \text {-month clinical } \\
\text { follow-up }\end{array}$ \\
\hline $\begin{array}{l}\text { Collins and } \\
\text { Altman (2013) }\end{array}$ & UK & $\begin{array}{l}\text { Retrospective series } \\
\text { using the THIN database }\end{array}$ & 2145133 & 2283 & $\begin{array}{l}\text { 2-year follow-up in } \\
\text { primary care records }\end{array}$ \\
\hline Deyo (1988) & US & $\begin{array}{l}\text { Prospective series from a } \\
\text { walk-in clinic }\end{array}$ & 1975 & 1 & $\begin{array}{l}\geq 18 \text {-month follow-up } \\
\text { in institutional tumour } \\
\text { registry }\end{array}$ \\
\hline $\begin{array}{l}\text { Friedlander } \\
\text { (2014) }\end{array}$ & US & $\begin{array}{l}\text { Retrospective series } \\
\text { using the Vanderbilt } \\
\text { University Medical } \\
\text { Centre's Research } \\
\text { Derivative }\end{array}$ & 2455 & 49 & $\begin{array}{l}\text { 180-day follow-up in the } \\
\text { Vanderbilt University } \\
\text { Medical Centre's } \\
\text { Research Derivative }\end{array}$ \\
\hline $\begin{array}{l}\text { Hippisley-Cox } \\
\text { and Coupland } \\
\text { (2012) }\end{array}$ & UK & $\begin{array}{l}\text { Prospective series using } \\
\text { patients in the QResearch } \\
\text { database (version 30) }\end{array}$ & 1240722 & 1622 & $\begin{array}{l}\text { 2-year follow-up in } \\
\text { primary care records }\end{array}$ \\
\hline Jones (2007) & UK & $\begin{array}{c}\text { Retrospective series } \\
\text { using the GPRDa }\end{array}$ & 11108 & 634 & $\begin{array}{l}\text { 3-year follow-up in } \\
\text { primary care records }\end{array}$ \\
\hline Muris (1995) & $\begin{array}{l}\text { The } \\
\text { Netherlands }\end{array}$ & $\begin{array}{l}\text { Prospective series from } \\
80 / 460 \text { GPs in Limburg }\end{array}$ & 933 & 1 & $\begin{array}{l}\text { Follow-up for } \geq 12 \\
\text { months (mean }=18 \\
\text { months) }\end{array}$ \\
\hline $\begin{array}{l}\text { Oudega } \\
\text { (2006) }\end{array}$ & $\begin{array}{l}\text { The } \\
\text { Netherlands }\end{array}$ & $\begin{array}{l}\text { Prospective series from } \\
\text { all } 50 \text { primary care } \\
\text { physicians within } \\
\text { a catchment area } \\
\text { ( 130 } 000 \text { inhabitants) of a } \\
\text { non-teaching hospital }\end{array}$ & 430 & $5^{b}$ & $\begin{array}{l}\text { 2-year follow-up in } \\
\text { primary care records }\end{array}$ \\
\hline $\begin{array}{l}\text { Price (2014)/ } \\
\text { Shephard } \\
\text { (2012) }\end{array}$ & UK & $\begin{array}{c}\text { Matched case-control } \\
\text { study using patients in the } \\
\text { GPRDa }\end{array}$ & 21718 & 4915 & $\begin{array}{l}\text { Bladder cancer code in } \\
\text { the UK's GPRD }\end{array}$ \\
\hline $\begin{array}{l}\text { Shephard } \\
\text { (2013) }\end{array}$ & UK & $\begin{array}{l}\text { Matched case-control } \\
\text { study using patients in the } \\
\text { GPRDa }\end{array}$ & 14091 & 3149 & $\begin{array}{l}\text { Renal cancer code in the } \\
\text { UK's GPRD }\end{array}$ \\
\hline
\end{tabular}

${ }^{a}$ The GPRD has since been renamed the Clinical Practice Research Datalink (CPRD). ${ }^{\circ}$ The study reports only on prevalence of urogenital' malignancies as a whole and not split by urological or genital categories. GPRD = General Practice Research Database.

\section{Table 2. Risk of bias assessment for the included trials}

\begin{tabular}{|c|c|c|c|c|c|c|c|}
\hline \multirow[b]{2}{*}{ Study } & \multicolumn{4}{|c|}{ Risk of bias } & \multicolumn{3}{|c|}{ Applicability concerns } \\
\hline & $\begin{array}{l}\text { Patient } \\
\text { selection }\end{array}$ & $\begin{array}{c}\text { Index } \\
\text { test }\end{array}$ & $\begin{array}{l}\text { Reference } \\
\text { standard }\end{array}$ & $\begin{array}{c}\text { Flow and } \\
\text { timing }\end{array}$ & $\begin{array}{l}\text { Patient } \\
\text { selection }\end{array}$ & $\begin{array}{c}\text { Index } \\
\text { test }\end{array}$ & $\begin{array}{c}\text { Reference } \\
\text { standard }\end{array}$ \\
\hline Bruyninckx (2003) & $\checkmark$ & $\checkmark$ & $\checkmark$ & $\checkmark$ & $?$ & $\checkmark$ & $\checkmark$ \\
\hline Collins and Altman (2013) & 2 & 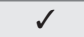 & $\checkmark$ & $\checkmark$ & 2 & $\checkmark$ & $\checkmark$ \\
\hline Deyo (1988) & ? & $\checkmark$ & ? & $\checkmark$ & $\mathrm{x}$ & $\checkmark$ & $\checkmark$ \\
\hline Friedlander (2014) & $\checkmark$ & $\checkmark$ & $?$ & $\checkmark$ & $?$ & $\checkmark$ & $\checkmark$ \\
\hline $\begin{array}{l}\text { Hippisley-Cox and } \\
\text { Coupland (2012) }\end{array}$ & $\checkmark$ & $\checkmark$ & $\checkmark$ & $x$ & $\checkmark$ & $\checkmark$ & $\checkmark$ \\
\hline Jones (2007) & d & $\checkmark$ & $\checkmark$ & $\checkmark$ & d & 2 & $\checkmark$ \\
\hline Muris (1995) & $x$ & $\checkmark$ & $\checkmark$ & $\checkmark$ & $\mathrm{x}$ & $x$ & $\checkmark$ \\
\hline Oudega (2006) & $\checkmark$ & $\checkmark$ & $\checkmark$ & $\checkmark$ & $?$ & $\checkmark$ & $\checkmark$ \\
\hline $\begin{array}{l}\text { Price (2014)/ } \\
\text { Shephard (2012) }\end{array}$ & $\mathrm{x}$ & $\checkmark$ & $\checkmark$ & $\checkmark$ & $\checkmark$ & $\checkmark$ & $\checkmark$ \\
\hline Shephard (2013) & $x$ & $\checkmark$ & $\checkmark$ & $\checkmark$ & $d$ & $\checkmark$ & $\checkmark$ \\
\hline
\end{tabular}

haematuria; these were grouped under visible haematuria in the meta-analysis.,.$^{91-13}$

Two studies used the same dataset, but had different methods for identifying haematuria. Shephard et al, ${ }^{17}$ used only coded data in the main searchable files in the General Practice Research Database (GPRD); Price et al, 16 supplemented this with uncoded entries from data fields not normally available to researchers (the so-called 'free text'). Similarly, Jones et al,'13 Collins and Altman, ${ }^{9}$ and Hippisley-Cox and Coupland ${ }^{12}$ used only coded data.

The meta-analysis of haematuria includes data from five studies with a total of 70330 patients. ${ }^{8,9,11-13}$ Jones et al, ${ }_{13}^{13}$ presented PPVs for cancer within 6 months of symptom presentation and for within 3 years. This meta-analysed estimate includes the data for cancer within 3 years. The corresponding meta-analytic estimate was $4.8 \%(95 \% \mathrm{Cl}=$ 3.0 to 7.5$)$ when the data for cancer within 6 months of presentation were used instead. Because of the low number of studies in the meta-analyses, it was not possible to conduct sensitivity or subgroup analyses. Therefore, the individual PPVs of the studies included in the meta-analyses are also presented, which ranged from $2 \%,{ }^{11}$ through $4.2 \%$ at 6 months, ${ }^{13} 4.4 \%,{ }^{9} 4.7 \%$ at 3 years, ${ }^{13}$ and $6.5 \%{ }^{12}$ to $10.3 \% .{ }^{8}$

Symptom pairs. Four studies examined symptom pairs (findings are available from the authors on request).8.16-18 Overall, the presence of a second symptom increased the overall PPV for cancer. This was most striking for combinations including haematuria. The highest PPVs for haematuria combinations were reported by Bruyninckx et al, including several PPV estimates around $20 \%$ in males aged $>60$ years. Their methods combined prospective and retrospective data collection, with some unresolved discrepancies: ${ }^{19}$ furthermore, confidence intervals were wide, reflecting the small samples. Similarly, a small sample size for Shephard et al's subgroup analysis ${ }^{18}$ reporting a PPV over $5 \%$ for renal cancer in males $>60$ years with abdominal pain and microcytosis means that this result should also be used with caution. Other than this combination, and haematuria combinations, the PPVs of symptom pairs were generally below $1 \%$.

\section{DISCUSSION}

\section{Summary}

This is the first review of the features of bladder and renal cancer solely using data from primary care. Symptoms reported 


\begin{tabular}{|c|c|c|c|c|}
\hline Cancer & Study & Age group and sex & PPV\% 19 & $95 \% \mathrm{Cll}$ \\
\hline \multicolumn{5}{|l|}{ Visible haematuria } \\
\hline Bladder and renal & Meta-analysis & All 15-100 years & \multicolumn{2}{|c|}{$5.1(3.2 \text { to } 8.0)^{\mathrm{a}}$} \\
\hline Bladder & Shephard (2012) & All 40-59 years & \multicolumn{2}{|c|}{3.1 (1.0 to 9.8$)$} \\
\hline Bladder & Price (2014) & All 40-59 years & \multicolumn{2}{|c|}{$1.2(0.6$ to 2.3$)$} \\
\hline Renal & Shephard (2013) & All 40-59 years & \multicolumn{2}{|c|}{0.7 (0.4 to 1.3$)$} \\
\hline Bladder & Bruyninckx (2003) & All <60 years & \multicolumn{2}{|c|}{2.6 (0.9 to 6.2$)$} \\
\hline Bladder & Shephard (2012) & All $\geq 60$ years & \multicolumn{2}{|c|}{$3.9(3.5$ to 4.6$)$} \\
\hline Bladder & Price (2014) & All $\geq 60$ years & \multicolumn{2}{|c|}{$2.8(2.5$ to 3.1$)$} \\
\hline Renal & Shephard (2013) & All $\geq 60$ years & \multicolumn{2}{|c|}{1.0 (0.1 to 1.3$)$} \\
\hline \multicolumn{5}{|c|}{ Second primary care attendance with symptom } \\
\hline Bladder & Shephard (2012) & All $\geq 60$ years & \multirow{2}{*}{\multicolumn{2}{|c|}{$\begin{array}{l}6.1(5.1 \text { to } 8.2) \\
1.2(0.9 \text { to } 1.8)\end{array}$}} \\
\hline Renal & Shephard (2013) & All $\geq 60$ years & & \\
\hline Separated by sex & & & Males & Females \\
\hline Bladder and renal & Collins (2013) & $30-84$ years & 5.5 (5.2 to 5.8$)$ & 2.6 (2.3 to 2.8$)$ \\
\hline Bladder & Bruyninckx (2003) & $>59$ years & 22.1 (15.8 to 30.1$)$ & 8.3 (3.4 to 17.9 ) \\
\hline Bladder & Bruyninckx (2003) & From $<40$ years to $>60$ years & 514.2 (10.1 to 19.5$)$ & 5.1 (2.5 to 9.8) \\
\hline Bladder & Bruyninckx (2003) & $<40$ years & 0.0 (0.0 to 12.0) & 0.0 (NR) \\
\hline Bladder & Bruyninckx (2003) & 40-59 years & $3.6(0.6$ to 13.4$)$ & $6.4(1.7$ to 18.6$)$ \\
\hline Bladder and renal & Jones (2007) & $15-100$ years & $5.47(4.9 \text { to } 6.1)^{\mathrm{b}}$ & $2.48(2.1 \text { to } 3.0)^{b}$ \\
\hline Bladder and renal & Jones (2007) & $15-100$ years & $7.4(6.8$ to 8.1$)$ & 3.4 (2.9 to 4.0$)$ \\
\hline Bladder and renal & Jones (2007) & $<45$ years & $1(0.5$ to 1.7$)$ & $0.2(0.1$ to 0.6$)$ \\
\hline Bladder and renal & Jones (2007) & 45-54 years & $4.4(3.1$ to 5.9$)$ & 1.3 (0.7 to 2.5$)$ \\
\hline Bladder and renal & Jones (2007) & $55-64$ years & 8.5 (6.9 to 10.3 ) & $3.4(2.3$ to 4.9$)$ \\
\hline Bladder and renal & Jones (2007) & $65-74$ years & $11.2(9.7$ to 12.9$)$ & $5.9(4.4$ to 7.7$)$ \\
\hline Bladder and renal & Jones (2007) & $75-84$ years & 10.3 (8.6 to 12.1 ) & 6.8 (5.1 to 9.0 ) \\
\hline Bladder and renal & Jones (2007) & $\geq 85$ years & $9.2(6.4$ to 12.7$)$ & 8.5 (5.6 to 12.3 ) \\
\hline \multicolumn{5}{|c|}{ Non-visible haematuria } \\
\hline Bladder & Price (2014) & All 40-59 years & \multicolumn{2}{|c|}{$0.8(0.1$ to 5.6$)$} \\
\hline Bladder & Price (2014) & All $\geq 60$ years & \multicolumn{2}{|c|}{$1.6(1.2$ to 2.1$)$} \\
\hline \multicolumn{5}{|c|}{$\begin{array}{l}\text { aThe meta-analysis of haematuria includes data from five studies with a total of } 70330 \text { patients. Jones (2007) } \\
\text { presented PPVs for both cancer within } 6 \text { months of symptom presentation and within } 3 \text { years. The meta-analysis } \\
\text { includes the data for cancer within } 3 \text { years. }{ }^{6} \text { This estimate is for cancer within } 6 \text { months of presentation. The } \\
\text { remainder of the Jones (2007) estimates are for cancer within } 3 \text { years of symptom presentation. NR= not reported. } \\
\text { PPV= positive predictive value. }\end{array}$} \\
\hline
\end{tabular}

from secondary care were generally also predictive in the primary care population, although - as expected - the only high-risk symptom was haematuria. The summary PPV for haematuria for bladder or renal cancer in ages 15-100 years was 5.1\% 195\% $\mathrm{Cl}=3.2$ to 8.0 ), with the individual studies showing that the risk increased with age. The risk also increased when there were additional symptoms or when the patient reattended with unresolved haematuria. Haematuria was a stronger predictor of cancer in males, with PPVs generally around twice that of females. For other symptoms, including those of possible urinary tract infection, the risks were generally below $1 \%$, although again they were higher in males, and with increasing age.

\section{Strengths and limitations}

This review followed best-practice methods. ${ }^{20}$ In particular, the setting for the inclusion of studies was primary care. This was crucial for the clinical question to be answered - which patients presenting to primary care may have a urological cancer, and so may benefit from investigation or referral? Reviews including patients in the referred population generally find stronger associations between symptoms and disease, and are much less helpful in informing referral decisions.

As with any review, the findings depend on the quality of the original studies. The more recent ones using electronic research databases were of high quality. Three of these used case-control methods, ${ }^{16-18}$ which can lead to bias from patient selection. In this case, however, all patients present in the GPRD were used, reducing this concern. Three of the older papers used settings not fully representative of UK primary care, ${ }^{10,14,15}$ and in these the focus of the study was not urological cancer. It 
had been intended to examine prostate and testicular cancers, but only very few data were found on prostate cancer, for example, in Hamilton et al. ${ }^{5}$

\section{Implications for practice}

Patients would like to have cancer investigation even when the likelihood of cancer is as low as $1 \%,{ }^{21}$ although

\section{Table 4. Positive predictive values for bladder/renal cancer for non-haematuria symptoms, including urinary tract infection features}

\begin{tabular}{|c|c|c|c|c|c|}
\hline Cancer & Study & Symptom & Age group and sex & $\begin{array}{l}\text { Frequency of symptoms } \\
\text { in patients with } \\
\text { urinary tract cancer }\end{array}$ & PPV $\%(95 \% \mathrm{Cl})$ \\
\hline Bladder & Shephard (2012) & Urinary tract infection & $\geq 60$ years & $759 / 4358=17 \%$ & $0.4(0.3$ to 0.4$)$ \\
\hline Renal & Shephard (2013) & Lower urinary tract infection & $\geq 60$ years & $280 / 2454=11 \%$ & $0.1(0.09$ to 0.1$)$ \\
\hline Bladder & Shephard (2012) & Urinary tract infection (reattendance) & $\geq 60$ years & $308 / 4358=7 \%$ & $0.5(0.4$ to 1.6$)$ \\
\hline Renal & Shephard (2013) & Lower urinary tract infection (reattendance) & $\geq 60$ years & $92 / 2454=4 \%$ & $0.1(0.1$ to 0.2$)$ \\
\hline Bladder and renal & Collins (2013) & Abdominal pain & $30-84$ years & $284 / 2283=12 \%$ & $0.1(0.1$ to 0.1$)$ \\
\hline Bladder and renal & Hippisley-Cox (2012) & Abdominal pain & $30-84$ years & $182 / 1622=11 \%$ & $0.2(0.2$ to 0.2$)$ \\
\hline Bladder and renal & Collins (2013) & Abdominal pain & Males $30-84$ years & $187 / 1685=11 \%$ & $0.2(0.2$ to 0.21$)$ \\
\hline Bladder and renal & Collins (2013) & Abdominal pain & Females $30-84$ years & $97 / 598=16 \%$ & $0.1(0.1$ to 0.1$)$ \\
\hline Bladder & Shephard (2012) & Abdominal pain & $\geq 60$ years & $313 / 4358=7 \%$ & $0.2(0.1$ to 0.2$)$ \\
\hline Renal & Shephard (2013) & Abdominal pain & $\geq 60$ years & $271 / 2454=11 \%$ & $0.1(0.1$ to 0.2$)$ \\
\hline Bladder & Shephard (2012) & Abdominal pain (reattendance) & $\geq 60$ years & $109 / 4358=3 \%$ & 0.2 (0.1 to 0.2 ) \\
\hline Renal & Shephard (2013) & Abdominal pain (reattendance) & $\geq 60$ years & $82 / 2454=3 \%$ & $0.2(0.1$ to 0.2$)$ \\
\hline Renal & Muris (1995) & Non-acute abdominal complaints & $18-75$ years & NR & $0.1(0.01$ to 0.7$)$ \\
\hline Renal & Deyo (1988) & Back pain & $15-86$ years & NR & 0.05 (0.002 to 0.3 \\
\hline Renal & Shephard (2013) & Back pain & $\geq 60$ years & $264 / 2454=11 \%$ & 0.1 (0.1 to 0.1$)$ \\
\hline Renal & Shephard (2013) & Back pain (reattendance) & $\geq 60$ years & $72 / 2454=3 \%$ & $0.1(0.1$ to 0.1$)$ \\
\hline Bladder & Shephard (2012) & Dysuria & $\geq 60$ years & $382 / 4358=9 \%$ & $0.7(0.6$ to 0.8$)$ \\
\hline Bladder & Shephard (2012) & Dysuria (reattendance) & $\geq 60$ years & $116 / 4358=3 \%$ & 1 (0.7 to 1.5$)$ \\
\hline Renal & Shephard (2013) & Fatigue & $\geq 60$ years & $170 / 2454=7 \%$ & $0.1(0.1$ to 0.1$)$ \\
\hline Renal & Shephard (2013) & Fatigue (reattendance) & $\geq 60$ years & $25 / 2454=1 \%$ & $0.1(0.1$ to 0.2$)$ \\
\hline Renal & Shephard (2013) & Constipation & $\geq 60$ years & $170 / 2454=7 \%$ & $0.1(0.1$ to 0.1$)$ \\
\hline Bladder & Shephard (2012) & Constipation & $\geq 60$ years & $270 / 4358=6 \%$ & 0.1 (0.1 to 0.2 ) \\
\hline Bladder & Shephard (2012) & Constipation (reattendance) & $\geq 60$ years & $73 / 4358=2 \%$ & $0.1(0.1$ to 0.2$)$ \\
\hline Renal & Shephard (2013) & Constipation (reattendance) & $\geq 60$ years & $41 / 2454=2 \%$ & $0.1(0.1$ to 0.1$)$ \\
\hline Renal & Shephard (2013) & Nausea & $\geq 60$ years & $140 / 2454=6 \%$ & 0.1 (0.1 to 0.2 ) \\
\hline Renal & Shephard (2013) & Nausea (reattendance) & $\geq 60$ years & $39 / 2454=2 \%$ & $0.2(0.1$ to 0.2$)$ \\
\hline Bladder and renal & Hippisley-Cox (2012) & Appetite loss & 30-84 years & $6 / 1622=0.4 \%$ & $0.2(0.1$ to 0.4$)$ \\
\hline Bladder and renal & Collins (2013) & Appetite loss & Females $30-84$ years & $4 / 598=0.7 \%$ & 0.1 (0.04 to 0.3 ) \\
\hline Renal & Oudega (2006) & Deep vein thrombosis & $\begin{array}{l}\text { With mean age }=60.7 \\
\quad(S D=18.2) \text { years }\end{array}$ & NR & $1.2(0.4$ to 2.9$)$ \\
\hline
\end{tabular}

$N R=$ not reported. $P P V=$ positive predictive value.

Table 5. Positive predictive values for bladder/renal cancer for blood test results, including anaemia features

\begin{tabular}{|c|c|c|c|c|c|}
\hline Cancer & Study & Symptom & Age group and sex & $\begin{array}{l}\text { Frequency of symptoms } \\
\text { in patients with } \\
\text { urinary tract cancer }\end{array}$ & PPV\% $(95 \% \mathrm{Cl})$ \\
\hline Renal & Shephard (2013) & Raised inflammatory markers & $\geq 60$ years & $640 / 2454=26 \%$ & 0.2 (0.1 to 0.2 ) \\
\hline Bladder & Shephard (2012) & Raised inflammatory markers & $\geq 60$ years & $271 / 4358=6 \%$ & $0.1(0.1$ to 0.2$)$ \\
\hline Bladder & Shephard (2012) & Raised creatinine & $\geq 60$ years & $648 / 4358=15 \%$ & $0.1(0.1$ to 0.1$)$ \\
\hline Renal & Shephard (2013) & Thrombocytosis & $\geq 60$ years & $289 / 2454=12 \%$ & 0.3 (0.2 to 0.3$)$ \\
\hline Renal & Shephard (2013) & Microcytosis & $\geq 60$ years & $194 / 2454=8 \%$ & $0.3(0.2$ to 0.4$)$ \\
\hline Bladder & Shephard (2012) & Raised white blood cell count & $\geq 60$ years & $222 / 4358=5 \%$ & $0.2(0.2$ to 0.2$)$ \\
\hline Bladder and renal & Collins (2013) & Anaemia & $30-84$ years & $102 / 2283=4 \%$ & 0.6 (0.5 to 0.7$)$ \\
\hline Bladder and renal & Hippisley-Cox (2012) & Anaemia & $30-84$ years & $68 / 1622=4 \%$ & $0.69(0.5$ to 0.9$)$ \\
\hline Bladder and renal & Collins (2013) & Anaemia & Males $30-84$ years & $57 / 1685=3 \%$ & $1.4(1.1$ to 1.9$)$ \\
\hline Bladder and renal & Collins (2013) & Anaemia & Females $30-84$ years & $45 / 598=8 \%$ & $0.3(0.3$ to 0.5$)$ \\
\hline
\end{tabular}

$P P V=$ positive predictive value. 


\section{Funding}

This article presents a systematic review undertaken as part of the 2015 NICE guideline on Suspected cancer: recognition and referral, which was developed by the National Collaborating Centre for Cancer (NCC-C). The NCC-C receives funding from the National Institute for Health and Care Excellence (NICE). William Hamilton is part-funded by the National Institute for Health Research (NIHR) Collaboration for Leadership in Applied Health Research and Care (CLAHRC) for the South West Peninsula at the Royal Devon and Exeter NHS Foundation Trust. This article was not subject to any further funding. The views expressed in this publication are those of the authors and not necessarily those of the NHS, NICE, the NIHR, or the Department of Health in England.

\section{Provenance}

Freely submitted; externally peer reviewed.

\section{Competing interests}

The authors have declared no competing interests.

\section{Acknowledgements}

The authors thank NICE, the NCC-C, and the Guideline Development Group for the Suspected cancer: recognition and referral NICE Guideline (2015).

\section{Discuss this article}

Contribute and read comments about this article: bjgp.org/letters

provision of cancer investigative services in the UK has generally been set using higher risk thresholds than this. Indeed, the 2015 revision of NICE guidance ${ }^{4}$ used a risk of cancer of $3 \%$ to underpin referral recommendations for suspected cancer. There is little health-economic evidence in urological cancer to help guide investigation decisions.

As there is considerable overlap between the symptoms of renal and bladder cancers, investigation of symptoms generally considers both together. This clinical practice has been particularly notable in the investigation of haematuria, with the initial testing strategy for bladder cancer being cystoscopy and for renal cancer being imaging, usually by ultrasound. The results of this systematic review support this, with a PPV for combined bladder or renal cancer for haematuria of $5.1 \%$. Prostate cancer may also present with haematuria, with a PPV estimate of $1.0 \%(95 \% \mathrm{Cl}=0.6$ to 1.8$)$ in one of the few papers found. ${ }^{5}$ Therefore the PPV of haematuria for urological cancer as a whole is probably even higher than the value from this meta-analysis. In addition, haematuria accompanied by additional symptoms (details are available from the authors on request) often had a considerably higher PPV - although generally the combinations with high PPVs had wide confidence intervals, so caution must be exercised. Only one study reported the risk of bladder cancer with invisible, or microscopic, haematuria. The risk of cancer was lower than for visible haematuria, so investigation of an unexpected positive test for invisible haematuria is unlikely to be warranted, unless there are additional features raising the likelihood of cancer. The risk of cancer with haematuria is age-dependent; a lower age threshold for investigation could be set, below which the benefits of identifying the occasional urological cancer may be exceeded by the costs of doing so.

Urinary tract infection can be a feature of urological cancer, particularly bladder cancer. The risks from documented infection per se, or from the main symptom of dysuria, were small, with reattendance to primary care with a complaint of dysuria in a patient $>60$ years the highest risk presentation of these; at $1 \%(95 \% \mathrm{Cl}=0.7$ to 1.5$)$ for bladder cancer. Thus it appears unnecessary for isolated urinary tract infection to be investigated, even in older patients. However, if it is accompanied by haematuria, it seems appropriate to treat the infection and check if the haematuria persists. Similarly, recurrent urinary infection in older patients may be the only feature of a bladder cancer, even if this is rare.

In other cancer sites, the risk of cancer rises with multiple symptoms. ${ }^{22,23}$ This was also the case for urological cancer in this review, although non-haematuria combinations all appeared to be of relatively low risk.

This systematic review of the features of bladder or renal cancer in primary care was dominated by the haematuria findings. Current practice for investigation of haematuria for possible cancer is well established, although no health-economic analyses have addressed the subject. Furthermore, not all patients with one of these cancers actually experience haematuria, so a policy restricting investigation to patients with haematuria will inevitably delay the diagnosis in some patients. That said, the low PPVs of the nonhaematuria presentations make selection of patients for investigation a considerable challenge. 


\section{REFERENCES}

1. Cancer Research UK. All cancers combined key facts. 2013. http://www cancerresearchuk.org/health-professional/cancer-statistics laccessed $1 \mathrm{Apr}$ 2015).

2. Elliss-Brookes L, McPhail S, Ives A, et al. Routes to diagnosis for cancer determining the patient journey using multiple routine data sets. Br J Cancer 2012; 107(8): 1220-1226.

3. Barrett J, Hamilton W. Pathways to the diagnosis of prostate cancer in a British city. A population-based study. Scand J Urol Nephrol 2005; 39(4): 267-270.

4. National Institute for Health and Care Excellence. Suspected cancer: recognition and referral. NICE quideline. NG12. http://www.nice.org.uk/guidance/ng12/ resources/suspected-cancer-recognition-and-referral-1837268071621 laccessed 25 Sep 2015).

5. Hamilton W, Sharp DJ, Peters TJ, Round AP. Clinical features of prostate cancer before diagnosis: a population-based case-control study. Br J Gen Pract 2006; 56(531): 756-762.

6. Whiting PF, Rutjes AW, Westwood ME, et al. QUADAS-2: a revised tool for the quality assessment of diagnostic accuracy studies. Ann Intern Med 2011; 155(8): 529-536.

7. Leeflang MM, Deeks JJ, Rutjes AW, et al. Bivariate meta-analysis of predictive values of diagnostic tests can be an alternative to bivariate meta-analysis of sensitivity and specificity. J Clin Epidemiol 2012; 65(10): 1088-1097.

8. Bruyninckx R, Buntinx F, Aertgeerts B, Van Casteren V. The diagnostic value of macroscopic haematuria for the diagnosis of urological cancer in general practice. Br J Gen Pract 2003; 53(486): 31-35.

9. Collins GS, Altman DG. Identifying patients with undetected renal tract cancer in primary care: an independent and external validation of QCancer ${ }^{\circledR}$ (Renal) prediction model. Cancer Epidemiol 2013; 37(2): 115-120.

10. Deyo RA, Diehl AK. Cancer as a cause of back pain: frequency, clinical presentation, and diagnostic strategies. J Gen Intern Med 1988; 3(3): 230-238.

11. Friedlander DF, Resnick MJ, You C, et al. Variation in the intensity of hematuria evaluation: a target for primary care quality improvement. Am J Med 2014; 127(7): 633.e11-640.e11
12. Hippisley-Cox J, Coupland C. Identifying patients with suspected renal tract cancer in primary care: derivation and validation of an algorithm. Br J Gen Pract 2012; DOI: 10.3399/bjgp12X636074.

13. Jones R, Latinovic R, Charlton J, Gulliford MC. Alarm symptoms in early diagnosis of cancer in primary care: cohort study using General Practice Research Database. BMJ 2007; 334(7602): 1040

14. Muris JW, Starmans R, Fijten GH, et al. Non-acute abdominal complaints in general practice: diagnostic value of signs and symptoms. Br J Gen Pract 1995; 45(395): 313-316.

15. Oudega R, Moons KG, Karel Nieuwenhuis H, et al. Deep vein thrombosis in primary care: possible malignancy? Br J Gen Pract 2006; 56(530): 693-696.

16. Price SJ, Shephard EA, Stapley SA, et al. Non-visible versus visible haematuria and bladder cancer risk: a study of electronic records in primary care. $\mathrm{Br} J$ Gen Pract 2014; DOI: 10.3399/bjgp14X681409.

17. Shephard EA, Stapley S, Neal RD, et al. Clinical features of bladder cancer in primary care. Br J Gen Pract 2012; DOI: 10.3399/bjgp12X654560.

18. Shephard E, Neal R, Rose $P$, et al. Clinical features of kidney cancer in primary care: a case-control study using primary care records. Br J Gen Pract 2013; DOI: 10.3399/bjgp13X665215

19. Hay AD, Hamilton W, Sharp D, et al. Macroscopic haematuria and urological cancer. Br J Gen Pract 2003; 53(488): 241-243.

20. National Institute for Health and Care Excellence. Process and methods guides. The guidelines manual. PMG6. http://www.nice.org.uk/article/pmg6/resources/ non-guidance-the-guidelines-manual-pdf (accessed 25 Sep 2015).

21. Banks J, Hollinghurst $\mathrm{S}$, Bigwood L, et al. Preferences for cancer investigation: a vignette-based study of primary-care attendees. Lancet Oncol 2014; 15(2): 232-240.

22. Hippisley-Cox J, Coupland C. Identifying patients with suspected lung cancer in primary care: derivation and validation of an algorithm. Br J Gen Pract 2011; DOI: 10.3399/bjgp11X606627.

23. Stapley S, Peters TJ, Neal RD, et al. The risk of oesophago-gastric cancer in symptomatic patients in primary care: a large case-control study using electronic records. Br J Cancer 2013; 108(1): 25-31. 